\title{
INVESTIGATIONS ON CANOPY FEATURES OF THREE INDIGENOUS WOODLAND TREE SPECIES OF ETHIOPIA
}

\author{
Asferachew Abate ${ }^{1}$, Masresha Fetene ${ }^{2, *}$ and Zerihun Woldu ${ }^{2}$ \\ ${ }^{1}$ Ministry of Economic Development and Cooperation PO Box 1037 \\ Addis Ababa, Ethiopia \\ ${ }^{2}$ Department of Biology, Faculty of Science Addis Ababa University \\ PO Box 1176 Addis Ababa, Ethiopia
}

\begin{abstract}
Canopy features, diversity of undercanopy vegetation, and undercanopy soil chemical characteristics of three indigenous woodland tree species namely: Acacia tortilis (Forssk.) Hayne, Acacia senegal (L.) Willd, Balanites aegyptiaca (L.) Del. were studied. The objective of the study was to explore the potential of the tree species for use in agroforestry systems. The study was conducted at three different sites within the Great Rift Valley at Adamitulu area, Abijata Shalla and Awash National Parks. At each site a total of 15 study trees were selected from $50 \times 50 \mathrm{~m}$ relevès. From each tree, data on tree height, diameter at breast height (DBH), canopy depth and canopy diameter were collected. Effect of trees on undercanopy vegetation diversity was assessed by estimating cover of undercanopy herbaceous vegetation. Soil samples were collected beneath and outside tree canopies to investigate the influence of tree species on undercanopy soil. A. tortilis had the highest DBH $(0.42 \pm 0.12)$ and canopy diameter $(13.64 \pm 2.25)$ whereas the highest tree height $(5.18 \pm 0.77)$ and canopy depth $(2.94 \pm 0.73)$ were recorded for $B$. aegyptiaca. The highest undercanopy vegetation diversity was recorded for $A$. tortilis $(2.13)$ followed by $A$. senegal (1.92) and $B$. aegyptiaca (1.78). In general, surface soil organic carbon, total nitrogen, available phosphorus, exchangeable potassium, and electrical conductivity were higher under tree canopies for all the study trees compared to outside canopy soils. Soil conductivity, organic carbon, total nitrogen and available phosphorus were found to be highest for surface soils, under A. tortilis. However, no difference in soil nutrient content among the tree species were found at greater soil depth. Implications of the findings for agroforestry systems are discussed.
\end{abstract}

Key words/phrases: Acacia senegal, Acacia tortilis, Agroforestry, Balanites aegyptiaca, undercanopy soil property

* Author to whom all correspondence should be addressed. 


\section{INTRODUCTION}

The potential role woodland trees can play as multipurpose tree species has recently gained wider significance (Gutteridge and Shelton, 1993). This is more so in connection with the use of indigenous trees for agroforestry systems (Fagg and Stewart, 1994). To qualify for use as multipurpose species a tree should have a relatively fast growth rate and ability to improve soil fertility. It should also provide favourable microclimate for growing crops and forage under its canopy (Belsky et al., 1989). Thus, before considering trees for use in agroforestry systems, their growth characteristics, canopy features and soil improving capacity need to be assessed.

Ethiopia is endowed with a number of woodland trees that could be used as multipurpose tree species (De Vletter, 1991). However, very few studies have been done on their actual potential. Although limited data may have been obtained on some species from studies in other countries (Belsky et al., 1989; Belsky et al., 1993), the large variability that exists, depending on sites and varieties in the country, necessitate specific studies. The following study was conducted with this in mind. Three indigenous woodland trees, Acacia tortilis (Forssk.) Hayne, subspecies spirocarpa, Acacia senegal (L.) Willd variety senegal and Balanites aegyptiaca (L.) Del. variety aegyptiaca were studied to investigate their potential for use in agroforestry systems.

\section{MATERIALS AND METHODS}

\section{Sites}

The study was conducted at thiree different sites within the Ethiopian Rift Valley: at Adamitulu, about $220 \mathrm{~km}$ south of Addis Ababa along the road to Awassa (site-1), in the Awash National Park at about $10 \mathrm{~km}$ on the left side of the road from the main gate to the Head Quarter (site-2), and in the Abijata Shalla National Park (site-3). The altitude of sites-1 and 3 ranges between 1680-1740 m while the second site was at an altitude of about $1000 \mathrm{~m}$ above see level. Mean annual rainfall and temperature in the study areas range between $400-800 \mathrm{~mm}$ and $20-25^{\circ} \mathrm{C}$, respectively (EMA, 1988). All the sites were protected from livestock and based on information from the locality the sites had not been burnt at least for the past ten years. The effect of wildlife was also minimal. 


\section{Vegetation data and analysis}

Five representative relevès, having an area of $2500 \mathrm{~m}^{2}(50 \times 50 \mathrm{~m})$, were established in each of the three sites. Both establishment of relevès and data collection were performed in July, 1993. The relevès were established systematically to include $A$. tortilis, $A$. senegal and $B$. aegyptiaca at each relevè. When it was difficult to encompass all the trees within one relevè, a relevè was made to include at least two of the study trees and the third one was taken from the nearest possible distance from this relevè. In each of the relevè's the density of all tree species was recorded. Selection of trees for detailed studies was made on the basis that they were at least $10 \mathrm{~m}$ away from neighbouring trees. In each relevè one individual from each of the study trees was selected to measure tree height, diameter at breast height ( $\mathrm{DBH}$ ) approximately $1.5 \mathrm{~m}$ above the ground, canopy diameter and canopy depth. Canopy depth was measured as the distance between the bole, where bifurcation of branches begin, and the tip of the tree.

Under the canopies of each of the study trees, herbaceous vegetation was listed and their cover was estimated visually. Cover of outside canopy herbaceous vegetation was also estimated from $10 \times 10 \mathrm{~m}$ quadrats, which were made at least $3 \mathrm{~m}$ away from the edge of the tree canopies. Cover of outside canopy vegetation was compared with undereanopy vegetation to assess the effect of canopy on vegetation abundance and composition.

Undercanopy areas of all study trees and the corresponding outside tree canopy areas were considered as stands. Visually estimated cover values from these stands were converted into a modified Domin scale (Goldsmith et al., 1976). The converted cover values were used to calculate species diversity as a measure of species richness and relative abundance. The diversity in each stand was computed using the Shanon-Weaver diversity index (Goldsmith et al., 1976).

\section{Soil sample collection and analyses}

Six species were selected from each of the study trees and undercanopy soil samples were collected from $0-3,5-8$ and $20-23 \mathrm{~cm}$ depths along a transect from the bole to the edge of the canopy at a distance of 50,250 , and $450 \mathrm{~cm}$. Similarly, representative soil samples outside tree canopies, two from each site, were collected from an area where there was no vegetation. Electrical conductivity was determined by preparing a 1:2 soil/water suspension (Chopra and Kanwar, 1976). The Walkley and Black wet oxidation method was followed 
to determine organic carbon (Juo, 1978; Cottenie, 1980). Available phosphorus was determined following Bray No.1 procedure (Juo, 1978). Micro-Kjeldahl method was used to determine total nitrogen (Juo, 1978). Potassium was determined by extraction using ammonium acetate solution at $\mathrm{pH} 7$ (Teklu Baissa, 1992).

Mean values of conductivity, organic carbon, total nitrogen, available phosphorus and exchangeable potassium were used to compare the influence of trees on canopy soils at different depth and distance from the tree bole. Comparison of variation in soil properties among study trees were made by using the overall mean of a particular soil property.

\section{Statistical analysis}

The mean values of tree characteristics and the results obtained by soil analysis were compared using a two way analysis of variance and Tukey's test of significance using the MINITAB statistical software (version 10) at $5 \%$ confidence level.

\section{RESULTS}

The dominant species in all the three sites investigated were $A$. tortilis, $A$. senegal, $B$. aegyptiaca and $A$. seyal (Table 1 ). In addition the following trees were also recorded; $A$. mellifera, $A$. nubica, $A$. nilotica (only in site-2) and $A$. sieberiana (only in site-3). Grass and herb species dominant in site-1 were Cenchrus ciliaris, Hyparrhenia hirta, Chloris gayana, Cryptostegia grandiflora, Harpachne schimperi, Tagetes minuta, Solanum incanum, Bidens pilosa, Satureja abyssinica and Sida ovata. A complete list of undercanopy species and their cover values is given in appendices 1 and 2 .

Site-2 was dominated by the following grass species: Ischaemum afrum, Bothriochloa radicans, Chrysopogon plumulosus, Dactyloctenium scindicum and Cymbopogon excavatus. Barleria quadrispina was dominant among the herbs in site- 2 .

Grass and herb species dominant in site-3 were Cenchrus setigerus, Cenchrus ciliaris, Harpachne schimperi, Hypoestes forskaolii, Satureja abyssinica and Solanum incanum. 
Table 1. Density of species in each of the Relevé.

\begin{tabular}{|c|c|c|c|c|c|}
\hline \multirow{2}{*}{ Species } & \multicolumn{5}{|c|}{ Relevé/Density } \\
\hline & 1 & 2 & 3 & 4 & 5 \\
\hline \multicolumn{6}{|l|}{ Site-1 } \\
\hline$\overline{\text { Acacia tortilis }}$ & 13 & 9 & 4 & 8 & 7 \\
\hline A. senegal & 5 & 2 & 2 & 0 & 0 \\
\hline Balanites aegyptiaca & 3 & 1 & 0 & 0 & 0 \\
\hline A. seyal & 13 & 9 & 1 & 0 & 0 \\
\hline \multicolumn{6}{|l|}{$\underline{\text { Site-2 }}$} \\
\hline A. tortilis & 16 & 8 & 3 & 3 & 14 \\
\hline A. senegal & 14 & 19 & 9 & 51 & 16 \\
\hline B. aegyptiaca & 9 & 0 & 6 & 0 & 11 \\
\hline Cordia gharaf & 5 & 17 & 2 & 0 & 3 \\
\hline Grewia vilosa & 5 & 20 & 13 & 18 & 10 \\
\hline A. mellifera & 0 & 0 & 0 & 0 & 8 \\
\hline A. nubica & 0 & 0 & 137 & 0 & 18 \\
\hline A. nilotica & 0 & 1 & 0 & 0 & 0 \\
\hline Dobera glabra & 0 & 0 & 3 & 0 & 0 \\
\hline Grewia erythria & 1 & 0 & 0 & 2 & 7 \\
\hline \multicolumn{6}{|l|}{ Site-3 } \\
\hline A. tortilis & 37 & 26 & 39 & 25 & 25 \\
\hline A. senegal & 6 & 5 & 10 & 10 & 0 \\
\hline B. aegyptiaca & 8 & 18 & 12 & 7 & 2 \\
\hline A. seyal & 26 & 3 & 15 & 10 & 17 \\
\hline A. sieberiana & 0 & 0 & 0 & 4 & 3 \\
\hline
\end{tabular}

Site-3 had the highest tree density of the dominant species followed by sites- 2 and 1 with total mean values of 61,36 and 17 per relevè, respectively. However, the study trees in site- 1 were characterized by highest mean values of tree height, DBH and canopy diameter (Table 2) as well as diversity of undercanopy herbaceous species compared with sites- 2 and 3 . 


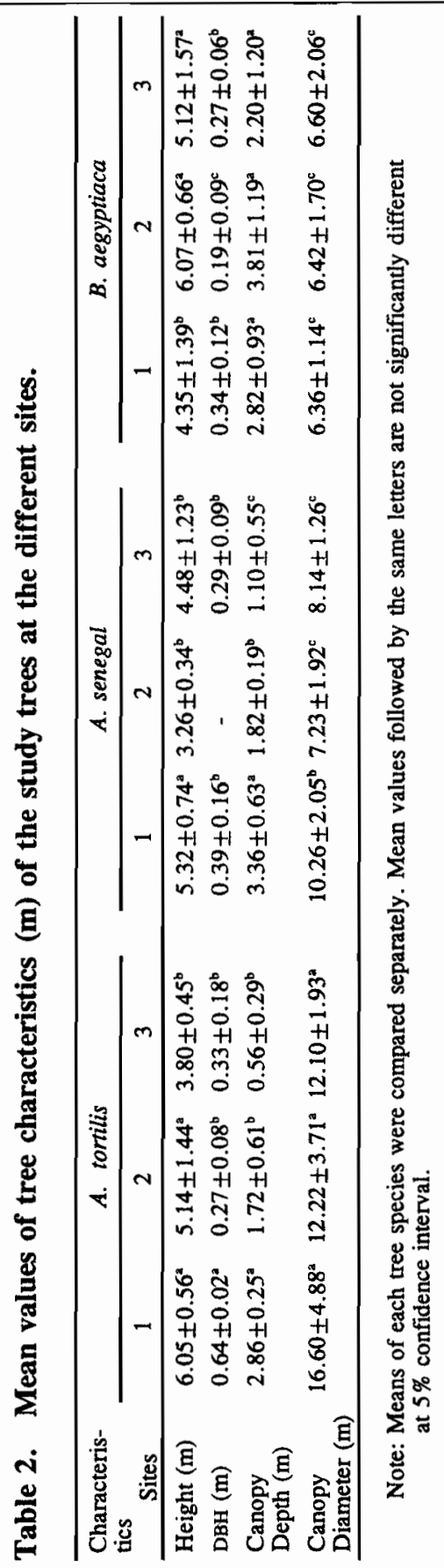


Taking tree characteristics in all sites together, the highest tree height $(5.18 \pm$ $0.77)$ and canopy depth $(2.94 \pm 0.73)$ were recorded for $B$. aegyptiaca. Trees of $A$. tortilis were relatively larger in size. They had the highest DBH and canopy diameter with means $0.42 \pm 0.12 \mathrm{~m}$ and $13.64 \pm 2.25 \mathrm{~m}$, respectively. Trees of $A$. tortilis, with their more or less flat crowns, had the lowest canopy depths $(1.71 \pm 0.58 \mathrm{~m})$.

Cover of undercanopy vegetation was highest $(124 \pm 21 \%)$ under $A$. tortilis followed by $A$. senegal $(110 \pm 21 \%)$ and $B$. aegyptiaca $(107 \pm 16.77 \%)$, respectively. $A$. tortilis had the highest diversity of species growing beneath its canopy in all the sites followed by $A$. senegal and $B$. aegyptiaca (Table 3 ). Comparison of the mean diversity indices of the study trees indicated that the diversity index of $A$. tortilis (2.13) was significantly higher compared with $\boldsymbol{B}$. aegyptiaca (1.78). Mean diversity indices of all the study trees were significantly higher than diversity indices of species outside tree canopies (Table 3 ).

Electrical conductance of soils under the study trees ranged from $0.05-0.80 \mathrm{~m}$ siemens $\mathrm{cm}^{-1}$. In all the sites, mean conductance was significantly higher in surface soils compared to soils outside tree canopies at $5 \%$ confidence level (Table 4). Comparison of undercanopy surface soils of the study trees revealed that mean conductance of $A$. tortilis was highest followed by $B$. aegyptiaca and A. senegal (Fig. 1). However, their difference was not significant at $5 \%$ confidence level.

Table 3. Mean diversity indices of undercanopy vegetation in each of the sites $(n=5)$.

\begin{tabular}{lcccc}
\hline Site no. & A. tortilis & A. senegal & B. aegyptiaca & Outside canopy \\
\hline 1 & 2.44 & 2.27 & 2.12 & 1.18 \\
2 & 1.91 & 1.84 & 1.70 & 0.76 \\
3 & 2.05 & 1.64 & 1.51 & 1.32 \\
Mean* & $2.13^{\mathrm{a}}$ & $1.92^{\mathrm{ab}}$ & $1.78^{\mathrm{b}}$ & $1.05^{\mathrm{c}}$ \\
\hline
\end{tabular}

* Mean diversity indices of the study trees in all sites $(n=15)$. Means followed by the same letters are not significantly different at $5 \%$ confidence interval. 
Table 4. Mean soil electrical conductivity (m siemens $\mathrm{cm}^{-1}$ ). Means followed by different letters are significantly different at $5 \%$ confidence level, $(n=6)(O C$, Outside Canopy).

\begin{tabular}{|c|c|c|c|c|c|c|c|c|c|c|}
\hline \multirow{2}{*}{$\begin{array}{l}\text { Depth }(\mathrm{cm}) \\
\text { Distance from } \\
\text { the bole }(\mathrm{cm})\end{array}$} & \multicolumn{3}{|c|}{ A. tortilis } & \multicolumn{3}{|c|}{ A. senegal } & \multicolumn{3}{|c|}{ B. aegyptiaca } & \multirow[b]{2}{*}{$\mathrm{OC}$} \\
\hline & 50 & 250 & 450 & 50 & 250 & 450 & 50 & 250 & 450 & \\
\hline $0-3$ & $0.80^{\mathrm{a}}$ & $0.73^{\mathrm{a}}$ & $0.57^{\mathrm{a}}$ & $0.71^{\mathrm{d}}$ & $0.54 d^{b}$ & $0.18 b^{c}$ & $0.76^{\mathrm{a}}$ & $0.47^{\mathrm{a}}$ & $0.47^{\mathrm{ab}}$ & $0.08^{c}$ \\
\hline $5-8$ & $0.40^{c}$ & $0.31^{\mathrm{b}}$ & $0.18^{\mathrm{a}}$ & $0.32^{\mathrm{d}}$ & $0.18^{b}$ & $0.10^{\mathrm{a}}$ & $0.54^{a}$ & $0.22^{\mathrm{b}}$ & $0.14^{b}$ & $0.11^{\mathrm{c}}$ \\
\hline $20-23$ & $0.28^{c}$ & $0.23^{b}$ & $0.12^{\mathrm{a}}$ & $0.17^{b}$ & $0.05^{b}$ & $0.11^{\mathrm{a}}$ & $0.47^{\mathrm{a}}$ & $0.32^{\mathrm{b}}$ & $0.28^{b}$ & $0.17^{\mathrm{c}}$ \\
\hline
\end{tabular}

\section{Electrical conductivity ( $\mathrm{m}$ siemens $\mathrm{cm}^{-1}$ )}

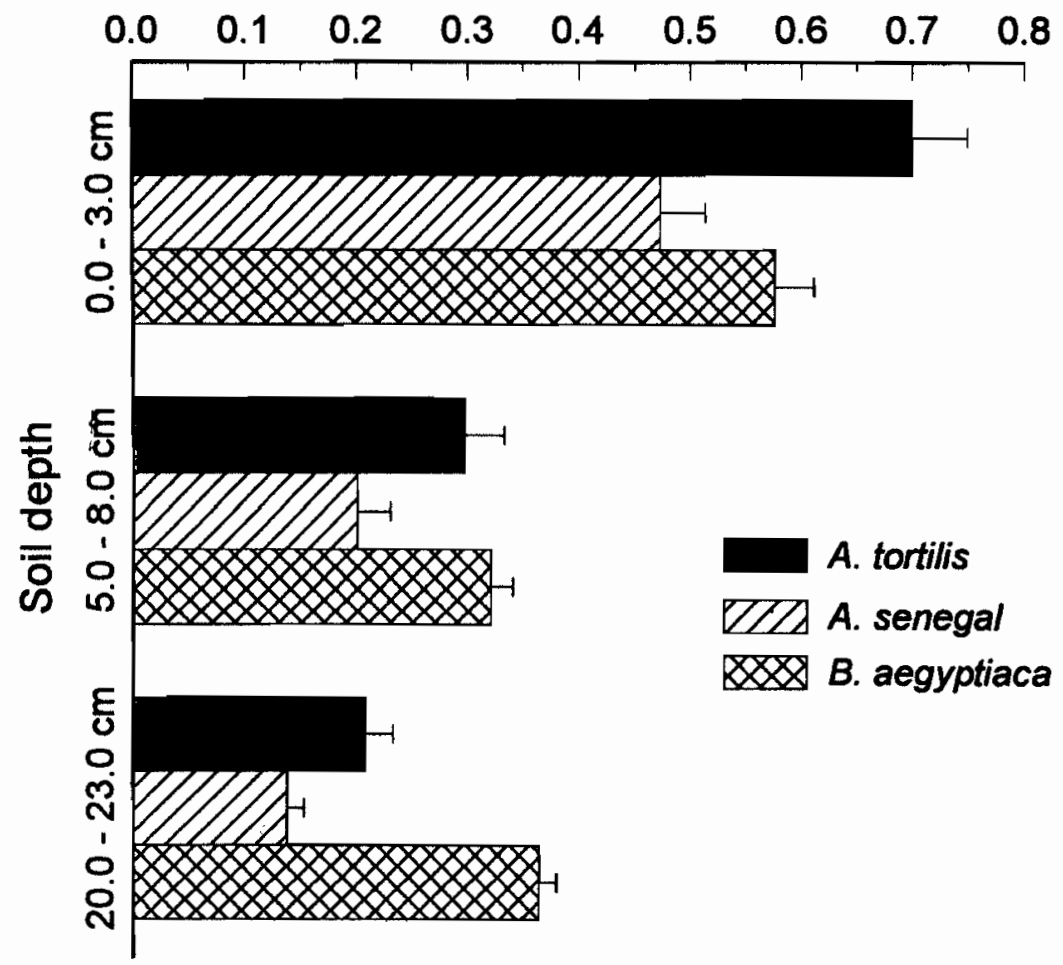

Fig. 1. Comparison of electrical conductivity of soils under the canopies of the tree species. $(\bar{x} \pm s d, n=18)$. 
Per cent organic carbon from undercanopy surface soils of all the tree species ranged from 1.84 to $5.36 \%$. In all the study trees organic carbon declined with soil depth. In addition, undercanopy surface soils of $A$. tortilis and $A$. senegal had significantly higher organic carbon compared to surface soils of outside tree canopies (Table 5). Comparison of the study trees among themselves showed that organic carbon of surface soils under $A$. tortilis were significantly higher than the surface soil under $B$. aegyptiaca. The organic carbon of surface soil under $A$. senegal exceeded surface soil of $B$. aegyptiaca. However, per cent organic carbon of soil samples at depths of 6.5 and $21.5 \mathrm{~cm}$ under $B$. aegyptiaca tended to be higher compared with soil samples under $A$. senegal of similar depths (Fig. 2).

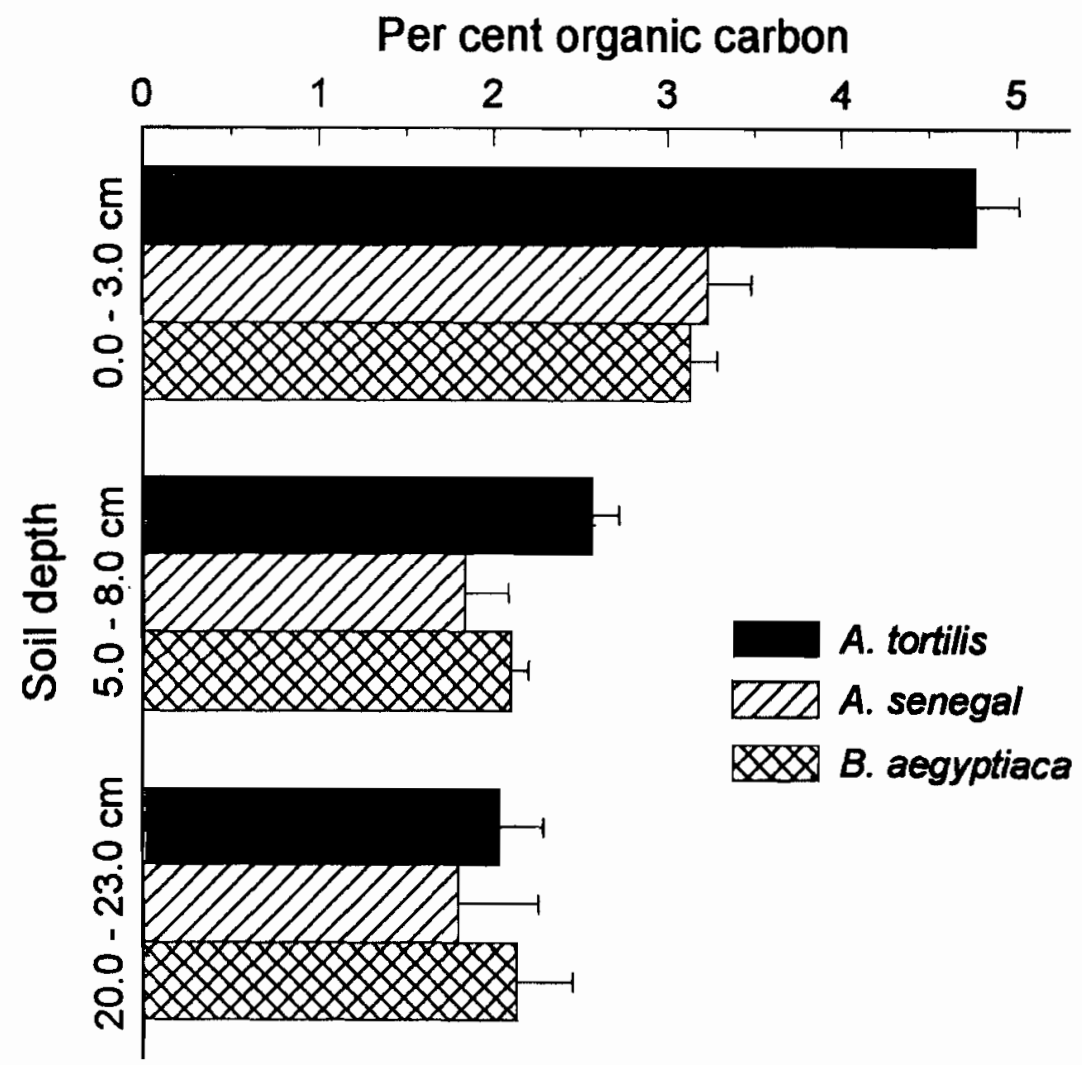

Fig. 2. Comparison of organic carbon of soils under the canopies of the tree species. $(\bar{x} \pm s d, n=18)$. 
Like organic carbon, total nitrogen tended to be higher in surface soils and declined with depth in all the study trees (Table 6 and 8). Total nitrogen in outside canopy soils tended to be lowest compared with undercanopy soils of all the study trees. However, the difference was not significant. Total nitrogen of surface soils under $A$. tortilis tended to be highest followed by $B$. aegyptiaca and $A$. senegal (Fig. 3). Total nitrogen of soils under $A$. senegal tended to be lower than under the non-legume $B$. aegyptiaca.

Table 5. Mean organic carbon (\%). Means followed by different letters are significantly different at $5 \%$ confidence interval, $(n=6)(O C$, outside canopy).

\begin{tabular}{|c|c|c|c|c|c|c|c|c|c|c|c|}
\hline \multirow[t]{2}{*}{ Depth $(\mathrm{cm})$} & \multirow{2}{*}{$\begin{array}{l}\text { Distance from } \\
\text { the bole }(\mathrm{cm})\end{array}$} & \multicolumn{3}{|c|}{ A. tortilis } & \multicolumn{3}{|c|}{ A. senegal } & \multicolumn{3}{|c|}{ B. aegyptiaca } & \multirow[b]{2}{*}{$\mathrm{OC}$} \\
\hline & & 50 & 250 & 450 & 50 & 250 & 450 & 50 & 250 & 450 & \\
\hline $0-3$ & & $4.10^{b}$ & $5.02^{b}$ & $5.36^{\mathrm{b}}$ & $4.53^{\mathrm{b}}$ & $3.42^{\mathrm{b}}$ & $1.84^{b}$ & 2.41 & $2.91^{2}$ & $4.24^{b}$ & $1.36^{\mathrm{a}}$ \\
\hline $5-8$ & & 2.10 & 2.54 & 2.12 & 2.46 & 1.83 & 1.53 & 2.77 & 1.79 & 1.58 & 1.23 \\
\hline $20-23$ & & 2.00 & 1.81 & 1.92 & 2.22 & 1.50 & 1.17 & 1.35 & 2.57 & 1.64 & 0.99 \\
\hline
\end{tabular}

Table 6. Mean total nitrogen (\%), $(n=6)$ (OC, outside canopy).

\begin{tabular}{|c|c|c|c|c|c|c|c|c|c|}
\hline \multirow[t]{2}{*}{ Depth $(\mathrm{cm})$} & \multirow{2}{*}{$\begin{array}{l}\text { Distance from } \\
\text { the bole }(\mathrm{cm})\end{array}$} & \multicolumn{3}{|c|}{ A. tortilis } & \multicolumn{2}{|c|}{ A. senegal } & \multicolumn{2}{|c|}{ B. aegyptiaca } & \multirow[b]{2}{*}{$O C$} \\
\hline & & 50 & 250 & 450 & 50 & $250 \quad 450$ & 50 & $250 \quad 450$ & \\
\hline $0-3$ & & 0.16 & 0.35 & 0.34 & 0.13 & 0.110 .05 & 0.27 & $\begin{array}{lll}0.15 & 0.37\end{array}$ & 0.09 \\
\hline $5-8$ & & 0.12 & 0.14 & 0.08 & 0.05 & 0.070 .05 & 0.09 & $0,120.16$ & 0.06 \\
\hline $20-23$ & & 0.11 & 0.14 & 0.08 & 0.06 & 0.050 .04 & 0.04 & 0.090 .22 & 0.05 \\
\hline
\end{tabular}

Available phosphorus also tended to be highest in surface soils. It ranged from $0.83-1.19 \mathrm{ppm}$ in $A$. tortilis, $0.28-0.71 \mathrm{ppm}$ in $A$. senegal and $0.21-0.45 \mathrm{ppm}$ in $B$. aegyptiaca (Tables 7 and 8 ). In general, available phosphorus declined with distance from the boles and with soil depth. Available phosphorus in surface soil collected under $A$. tortilis was significantly higher at $5 \%$ confidence level than surface soils under $A$. senegal and $B$. aegyptiaca (Fig. 4). 
Exchangeable potassium in undercanopy soils of $A$. tortilis and $A$. senegal ranged from 3.00-4.82 milli equivalent. Although not significantly, exchangeable potassium declined both with depth and distance from the bole under these trees. Unlike in the other two study trees, there was no regular pattern of change in exchangeable potassium with distance and depth for $B$. aegyptiaca. Surface soils of outside tree canopies had significantly lower exchangeable potassium compared with undercanopy soils of all the study trees. There was no significant variation in exchangeable potassium among the study trees.

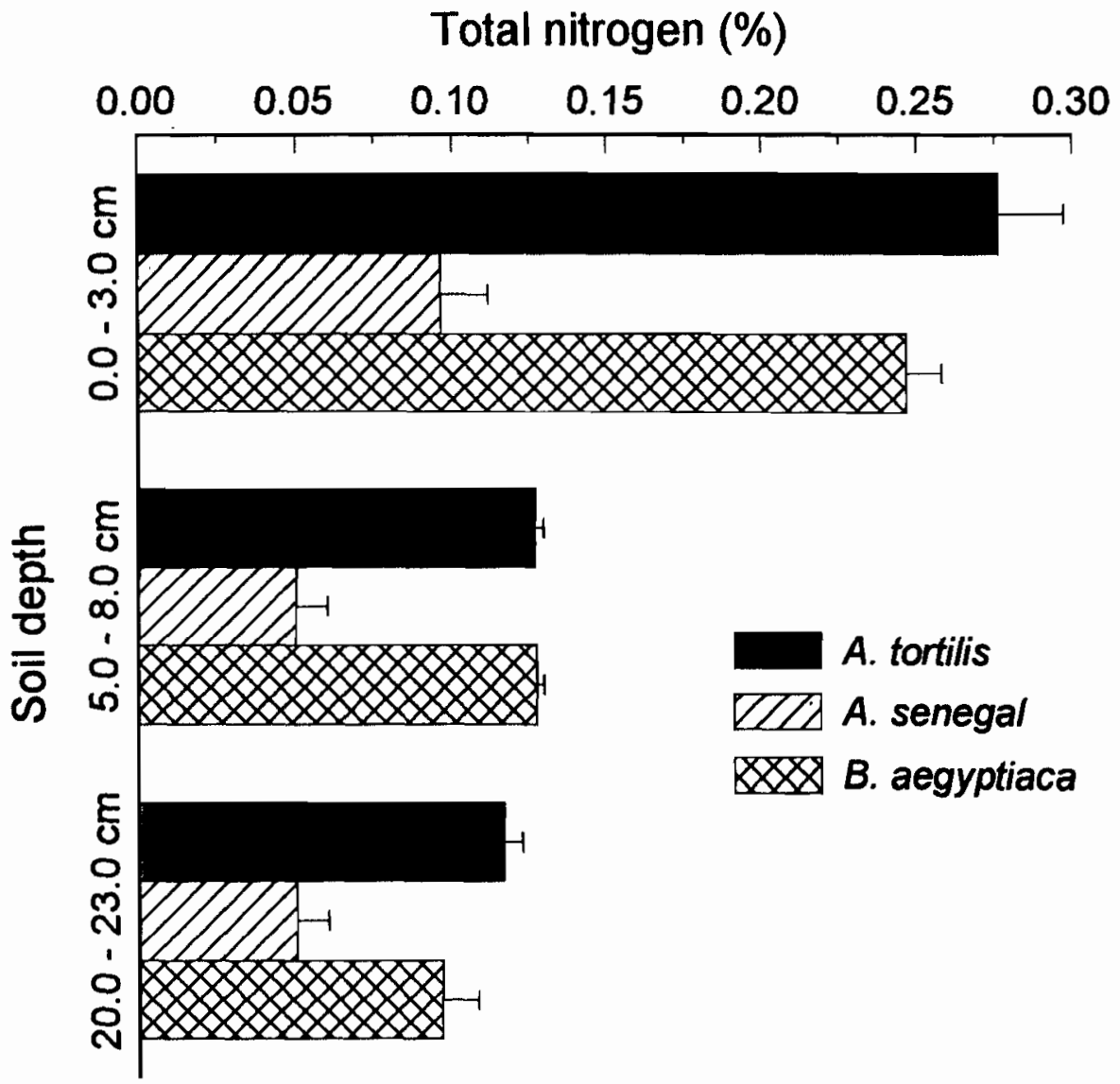

Fig. 3. Comparison of total nitrogen of soils under the canopies of the tree species. $(\bar{x} \pm s d, n=18)$. 
Table 7. Mean available phosphorus (ppm), $(n=6)$ (OC, outside canopy).

\begin{tabular}{|c|c|c|c|c|c|c|c|c|c|c|c|}
\hline \multirow{2}{*}{ Depth $(\mathrm{cm})$} & \multirow{2}{*}{$\begin{array}{l}\text { Distance from } \\
\text { the bole }(\mathrm{cm})\end{array}$} & \multicolumn{3}{|c|}{ A. tortilis } & \multicolumn{3}{|c|}{ A. senegal } & \multicolumn{3}{|c|}{ B. aegyptiaca } & \multirow[b]{2}{*}{ OC } \\
\hline & & 50 & 250 & 450 & 50 & 250 & 450 & 50 & 250 & 450 & \\
\hline $0-3$ & & 1.19 & 0.85 & 0.83 & 0.71 & 0.62 & 0.28 & 0.41 & 0.21 & 0.45 & 0.63 \\
\hline $5-8$ & & 0.42 & 0.43 & 0.24 & 0.43 & 0.16 & 0.19 & 0.26 & 0.22 & 0.18 & 0.38 \\
\hline $20-23$ & & 0.38 & 0.19 & 0.16 & 0.65 & 0.32 & 0.13 & 0.30 & 0.22 & 0.11 & 0.28 \\
\hline
\end{tabular}



Fig. 4. Comparison of available phosphorus of soils under the canopies of the tree species. $(\bar{x} \pm s d, n=18)$. 
Table 8. Two way analysis of variance table for the interaction of soil depth and distance from the bole within tree canopies.

\begin{tabular}{|c|c|c|c|c|c|}
\hline \multirow{2}{*}{ Species } & \multicolumn{5}{|c|}{ Electrical conductivity } \\
\hline & Source & DF & MS & $\mathrm{F}_{\text {ratio }}$ & $\mathbf{P}$ \\
\hline Acacia tortilis & $\begin{array}{l}\text { Depth } \\
\text { Distance } \\
\text { Dept. x Dist. }\end{array}$ & $\begin{array}{l}2 \\
2 \\
4\end{array}$ & $\begin{array}{l}1.223 \\
0.191 \\
0.002 \\
\end{array}$ & $\begin{array}{l}9.41 \\
1.47 \\
0.02 \\
\end{array}$ & $\begin{array}{l}<0.05 \\
>0.05 \\
>0.05\end{array}$ \\
\hline Acacia senegal & $\begin{array}{l}\text { Depth } \\
\text { Distance } \\
\text { Dept. } \times \text { Dist. }\end{array}$ & $\begin{array}{l}2 \\
2 \\
4\end{array}$ & $\begin{array}{l}0.359 \\
0.298 \\
0.100\end{array}$ & $\begin{array}{l}7.68 \\
6.38 \\
2.14 \\
\end{array}$ & $\begin{array}{l}<0.05 \\
<0.05 \\
>0.05\end{array}$ \\
\hline Balanities aegyptiaca & $\begin{array}{l}\text { Depth } \\
\text { Distance } \\
\text { Dept. x Dust. }\end{array}$ & $\begin{array}{l}2 \\
2 \\
4\end{array}$ & $\begin{array}{l}0.253 \\
0.575 \\
0.188\end{array}$ & $\begin{array}{l}3.58 \\
8.16 \\
0.27\end{array}$ & $\begin{array}{l}<0.05 \\
<0.05 \\
>0.05\end{array}$ \\
\hline & \multicolumn{5}{|c|}{ Organic carbon } \\
\hline A. tortilis & $\begin{array}{l}\text { Depth } \\
\text { Distance } \\
\text { Dept. x Dist. }\end{array}$ & $\begin{array}{l}2 \\
2 \\
4 \\
\end{array}$ & $\begin{array}{c}45.69 \\
0.93 \\
1.02 \\
\end{array}$ & $\begin{array}{l}8.41 \\
0.17 \\
0.19 \\
\end{array}$ & $\begin{array}{l}<0.05 \\
>0.05 \\
>0.05 \\
\end{array}$ \\
\hline A. senegal & $\begin{array}{l}\text { Depth } \\
\text { Distance } \\
\text { Dept. x Dist. }\end{array}$ & $\begin{array}{l}2 \\
2 \\
4\end{array}$ & $\begin{array}{c}13.52 \\
10.87 \\
1.56 \\
\end{array}$ & $\begin{array}{l}7.27 \\
5.84 \\
0.84 \\
\end{array}$ & $\begin{array}{l}<0.05 \\
<0.05 \\
>0.05\end{array}$ \\
\hline B. aegyptiaca & $\begin{array}{l}\text { Depth } \\
\text { Distance } \\
\text { Dept. x Dist. }\end{array}$ & $\begin{array}{l}2 \\
2 \\
4\end{array}$ & $\begin{array}{l}5.79 \\
1.10 \\
3.03\end{array}$ & $\begin{array}{l}1.63 \\
0.31 \\
0.85\end{array}$ & $\begin{array}{l}>0.05 \\
>0.05 \\
>0.05\end{array}$ \\
\hline & \multicolumn{5}{|c|}{ Total nitrogen } \\
\hline A. tortilis & $\begin{array}{l}\text { Depth } \\
\text { Distance } \\
\text { Dept. x Dist. }\end{array}$ & $\begin{array}{l}2 \\
2 \\
4\end{array}$ & $\begin{array}{l}0.183 \\
0.027 \\
0.024 \\
\end{array}$ & $\begin{array}{l}3.69 \\
0.55 \\
0.49 \\
\end{array}$ & $\begin{array}{l}<0.05 \\
>0.05 \\
>0.05\end{array}$ \\
\hline A. senegal & $\begin{array}{l}\text { Depth } \\
\text { Distance } \\
\text { Dept. x Dist. } \\
\end{array}$ & $\begin{array}{l}2 \\
2 \\
4 \\
\end{array}$ & $\begin{array}{l}0.011 \\
0.006 \\
0.003 \\
\end{array}$ & $\begin{array}{l}1.76 \\
0.99 \\
0.53 \\
\end{array}$ & $\begin{array}{l}>0.05 \\
>0.05 \\
>0.05 \\
\end{array}$ \\
\hline B. aegyptiaca & $\begin{array}{l}\text { Depth } \\
\text { Distance } \\
\text { Dept. x Dist } \\
\end{array}$ & $\begin{array}{l}2 \\
2 \\
4 \\
\end{array}$ & $\begin{array}{l}0.083 \\
0.006 \\
0.012 \\
\end{array}$ & $\begin{array}{l}4.10 \\
0.29 \\
0.61 \\
\end{array}$ & $\begin{array}{l}<0.05 \\
>0.05 \\
>0.05\end{array}$ \\
\hline & \multicolumn{5}{|c|}{ Available phosphorus } \\
\hline A. tortilis & $\begin{array}{l}\text { Depth } \\
\text { Distance } \\
\text { Dept. x Dist. }\end{array}$ & $\begin{array}{l}2 \\
2 \\
4 \\
\end{array}$ & $\begin{array}{l}2.557 \\
0.033 \\
0.039\end{array}$ & $\begin{array}{l}6.69 \\
0.87 \\
0.10 \\
\end{array}$ & $\begin{array}{l}<0.05 \\
>0.05 \\
>0.05\end{array}$ \\
\hline A. senegal & $\begin{array}{l}\text { Depth } \\
\text { Distance } \\
\text { Dept. x Dist. }\end{array}$ & $\begin{array}{l}2 \\
2 \\
4 \\
\end{array}$ & $\begin{array}{l}0.342 \\
0.721 \\
0.072 \\
\end{array}$ & $\begin{array}{l}2.55 \\
5.38 \\
0.54 \\
\end{array}$ & $\begin{array}{l}>0.05 \\
<0.05 \\
>0.05\end{array}$ \\
\hline B. aegyptiaca & $\begin{array}{l}\text { Depth } \\
\text { Distance } \\
\text { Dept. x Dist. }\end{array}$ & $\begin{array}{l}2 \\
2 \\
4\end{array}$ & $\begin{array}{l}0.047 \\
0.062 \\
0.012\end{array}$ & $\begin{array}{l}0.73 \\
0.96 \\
1.18\end{array}$ & $\begin{array}{l}>0.05 \\
>0.05 \\
>0.05\end{array}$ \\
\hline
\end{tabular}




\section{DISCUSSION}

This study revealed that a site with a high tree density may not necessarily have trees with desirable characteristics. Adamitulu area (site-1) had the lowest tree density while it contained trees with the highest height, the largest DBH, canopy depth, canopy diameter and canopy radius. On the other hand, Awash National Park (site-2) had the highest tree density whereas the lowest tree characteristics were recorded from this site. Both tree characteristics and tree density are influenced by inter- and intra-species competition. Thus, to effectively utilize the interaction of trees and herbs for crop and forage production as well as wood products from the trees, it might be necessary to optimize the number of tree species to be used per unit area (Karamchandani, 1989).

High abundance and diversity of herbaceous species under $A$. tortilis might be due to its large canopy diameter which allows for abundant growth of various species in the favourable undercanopy microclimate. Large shade of the canopy also minimizes run off by reducing the size and speed of raindrops which otherwise would result in loss of top soil from undercanopy.

High per cent vegetation cover and diversity of species under tree canopies compared to vegetation of outside canopies clearly showed that the species provide favourable environmental conditions which encourage higher growth of herbs and grasses beneath their canopies. Studies conducted so far to assess the important factors determining the abundance of understorey vegetation revealed that availability of soil moisture and nutrients are the key factors (Ben-Shahar, 1991).

Litter fall both from the canopy and understorey vegetation improves infiltration of precipitation by altering the physical and chemical properties of the soil and minimizing evapotranspiration. Kelly and Walker (1976) demonstrated that litter fall can improve the rate of infiltration compared to bare ground. The net effect of these factors would be improving undercanopy soil moisture. Together with soil nutrient content (see below) better soil moisture regime increase undercanopy vegetation abundance and diversity.

Soils are said to be in the normal range of concentration for soluble salts for most plant growth if their electrical conductances do not exceed $0.4 \mathrm{~m}$ siemens $\mathrm{cm}^{-1}$ (Donahue et al., 1983). Electrical conductivity well above $0.4 \mathrm{~m}$ siemens 
$\mathrm{cm}^{-1}$ were found from surface soils of most of the studied tree canopies. Although individual soluble salts were not quantified in the present study, it is possible that the high electrical conductivity values might be due to accumulation of $\mathrm{Na}^{+}, \mathrm{Ca}^{++}, \mathrm{Mg}^{++}, \mathrm{Cl}^{-}$and $\mathrm{SO}_{4}^{--}$(Thompson and Frederick, 1978). The values of electrical conductivity in the present study decreased with depth except for $B$. aegyptiaca. Increased soil conductivity with soil depth under $\boldsymbol{B}$. aegyptiaca $(20 \mathrm{~cm})$ might be due to leaching facilitated by the cylindrical shape of its canopy allowing much throughfall during the rainy season. Increase in conductivity with depth of outside canopy soil might also be attributed to leaching by rain that falls directly on the ground uninterrupted. Thus, significant difference of mean conductance between under and outside canopy soils indicated the influence of the trees on soil conductivity.

The relatively higher content of soil organic carbon under tree canopies indicated the soil enriching capacity of the trees. Although the values for nitrogen and phosphorus were not high, relatively more of these nutrients were found within tree canopies compared to outside canopy soils. Similar reports have been made by a number of workers who investigated the effect of tree canopies on plant nutrients (Garcia-Moya and Mckell, 1970; Charley and West, 1975; Kellman, 1979; Weltzin and Coughenour, 1990; Kamara and Haque, 1992).

The reason for higher content in the undercanopy soils could be complex (Vettas, 1992). Weltzin and Coughenour (1990) suggested that leaf fall from trees might be the most likely nutrient source. Dust accumulated on tree leaves and branches by wind blowing from the surroundings could also be a good source of mineral nutrients as it is washed down to undercanopy soil during stemflow and throughfall (Kellmann, 1979).

Woody species have deeper tap roots and extensive spreading lateral roots. Such root systems are probably important in concentrating nutrients under the canopy (Kellmann, 1979). Knoop and Walker (1985) suggested that nutrients found in low concentration throughout the soil profile may be taken up by the root system of mature trees and shrubs. These nutrients return back to undercanopy soil when tree leaves fall and decompose (Garcia-Moya and McKell, 1970).

Comparing the nitrogen content of undercanopy soils of the three trees (Fig. 3), soil under $A$. tortilis had more nitrogen followed by $B$. aegyptiaca and $A$. 
senegal. That the legume tree $A$. senegal had less nitrogen compared to the nonlegume tree $B$. aegyptiaca is surprising. Perhaps this might support the finding that not all trees that have the potential to fix atmospheric nitrogen actually do so (Garcia-Moya and McKell, 1970).

This study showed that all three species investigated had some qualities as agroforestry species, especially as related to their soil improving quality. From the study, it could be suggested that $A$. tortilis may be the choice tree for agroforestry in Adamitulu area whereas in the lower and more drier Awash National Park area Balanites aegyptiaca may be the better choice. However, more detailed studies on crop tree interactions, spacing, etc. are needed. Currently, seed germination and seedling establishment characteristics of these trees are under investigation in our laboratory.

\section{ACKNOWLEDGEMENTS}

The authors would like to acknowledge financial support from the School of Graduate Studies, Addis Ababa University and the African Academy of Sciences. We also thank anonymous reviewers of SINET for helpful suggestions.

\section{REFERENCES}

1. Belsky, A.J., Amundson, R.G., Duxbury, J.M., Riha, S.J., Ali, A.R. and Mwonga, S.M. (1989). The effects of trees on their physical, chemical, and biological environments in a semi-arid Savanna in Kenya. Journal of Applied Ecology 26:1004-1024.

2. Belsky, A.J., Mwonga, S.M., Amundson, R.G., Duxbury, J.M. and Ali, A.R. (1993). Comparative effects of isolated trees on their undercanopy environments in high and low rainfall savannas. Journal of Applied Ecology 30:143-155.

3. Ben-Shahar, R. (1991). Abundance of trees and grasses in a woodland savanna in relation to environmental factors. Journal of Vegetation Science 2:345-350.

4. Charley, J.L. and'West, N.E. (1975). Plant induced soil chemical patterns in some shrub-dominated semi-desert ecosystem of Utah. Journal of Ecology 63:945-963.

5. Chopra, S.L. and Kanwar, J.S. (1976). Analytical Agricultural Chemistry. Kalyani University Publishers, New Delhi.

6. Cottenie, A. (1980). Soil and Plant Testing as Basis of Fertilizer Recommendations. FAO, soil Bulletins no.38/2, Rome. 
7. De Vletter, J. (1991). Forest Genetic Resources of Ethiopia. Engels, J.M.M., Hawkes, J.G. and Melaku Worede (eds). Cambridge University Press, Cambridge.

8. Donahue, R.L., Miller, R.W. and Shickluna, J.C. (1983). Soils: An Introduction to Soils and Plant Growth. Prentice Hall of India, New Delhi.

9. Ethiopian Mapping Authority (EMA) (1988). National Atals of Ethiopia. Brehanena Selam Printing Press, Ethiopia.

10. Fagg, C.W. and Stewart, J.L. (1994). The value of Acacia and Prosopis in arid and Semi-arid environments. Journal of Arid environments 27:3-25.

11. Garcia-Moya, E. and McKell, C.M. (1970). Contribution of shrubs to the nitrogen economy of a desert-wash plant community. Ecology 51:81-88.

12. Goldsmith, F.B., Harrison, C.M. and Morton, A.J. (1976). Description and Analysis of Vegetation. In: Methods in Plant Ecology, pp. 437-524, (Moore, P.D. and Chapman, S.B., eds). Black Scientific Publications, Oxford.

13. Gutteridge, R.C. and Shelton, H.M. (1993). The scope and potential of tree legumes in agroforestry. Agroforestry Systems 23:177-194.

14. Juo, A.S.R. (ed.) (1978). Selected Methods for Soil and Plant Analysis. International Institute of tropical Agriculture, Ibadan, Nigeria.

15. Kamara, C.S. and Haque, I. (1992). Faidherbia albida and its effects on Ethiopian highland vertisols. Agroforestry Systems 18:17-29.

16. Karamchandani, K. (1989). The Development of Agroforestry and Rural Energy in Ethiopia Within the Frame Work of the National Food and Nutrition Strategy. FAO, Addis Ababa, Ethiopia.

17. Kellmann, M. (1979). Soil enrichment by neotropical savanna trees. Journal of Ecology 67:565-577.

18. Kelly, R.D. and Walker, B.H. (1976). The effects of different forms of land use on the ecology of a semi-arid region in south - eastern Rhodesia. Journal of Ecology 64:533-576.

19. Knoop, W.T. and Walker, B.H. (1985). Interaction of woody and herbaceous vegetation in a southern African savanna. Journal of Ecology 73:235-253.

20. Teklu Baissa (1992). National Soil Service Project, In service Training for Soil Laboratory Technicians. Ministry of Agriculture, Addis Ababa, Ethiopia.

21. Thompson, L.M. and Frederick, R.T. (1978). Soil and Soil Fertility. McGraw-Hill Publishing Company, New York.

22. Vettas, O.R. (1992). Micro-site effects of trees and shrubs in dry savannas. $J$. Vegetation Science 3:337-344.

23. Weltzin, J.K. and Coughenour, M.B. (1990). Savanna tree influence on understorey vegetation and soil nutrients in northwestern Kenya. Journal of Vegetation Science 1:325-334. 
Appendix 1. Tree and herbaceous undercanopy species occurring in the three study sites - Adamitulu, Awash and Abijata Shalla. The tree species are in five replicates A-E and the undercanopy species are represented by numbers with their per cent cover in parenthesis. The list of undercanopy species corresponding to the numbers are given in Appendix 2.

\begin{tabular}{|c|c|c|c|c|c|c|c|c|c|c|c|}
\hline \multirow[t]{5}{*}{ Adamitulu } & A & $\begin{array}{c}2 \\
18 \\
36\end{array}$ & $\begin{array}{l}(5.0) \\
(2.0) \\
(1.0)\end{array}$ & $\begin{array}{c}4 \\
25\end{array}$ & $\begin{array}{l}(1.0) \\
(1.0)\end{array}$ & $\begin{array}{c}6 \\
26\end{array}$ & $\begin{array}{l}(80.0) \\
(10.0)\end{array}$ & $\begin{array}{l}11 \\
34\end{array}$ & $\begin{array}{l}(1.0) \\
(2.0)\end{array}$ & $\begin{array}{l}13 \\
35\end{array}$ & $\begin{array}{l}(2.0) \\
(2.0)\end{array}$ \\
\hline & B & $\begin{array}{c}2 \\
11 \\
39\end{array}$ & $\begin{array}{r}(20.0) \\
(5.0) \\
(1.0)\end{array}$ & $\begin{array}{c}4 \\
26\end{array}$ & $\begin{array}{l}(1.0) \\
(6.0)\end{array}$ & $\begin{array}{c}5 \\
34\end{array}$ & $\begin{array}{l}(2.0) \\
(5.0)\end{array}$ & $\begin{array}{c}6 \\
37\end{array}$ & $\begin{array}{c}(60.0) \\
(5.0)\end{array}$ & $\begin{array}{l}10 \\
38\end{array}$ & $\begin{array}{c}(2.0) \\
(20.0)\end{array}$ \\
\hline & $\mathrm{C}$ & $\begin{array}{c}2 \\
34 \\
41\end{array}$ & $\begin{array}{c}(10.0) \\
(5.0) \\
(1.0)\end{array}$ & $\begin{array}{c}5 \\
36\end{array}$ & $\begin{array}{l}(2.0) \\
(1.0)\end{array}$ & $\begin{array}{r}6 \\
38\end{array}$ & $\begin{array}{l}(10.0) \\
(20.0)\end{array}$ & $\begin{array}{c}9 \\
39\end{array}$ & $\begin{array}{l}(1.0) \\
(1.0)\end{array}$ & $\begin{array}{l}11 \\
40\end{array}$ & $\begin{array}{c}(1.0) \\
(20.0)\end{array}$ \\
\hline & $\mathrm{D}$ & $\begin{array}{c}2 \\
11 \\
35\end{array}$ & $\begin{array}{c}(20.0) \\
(5.0) \\
(1.0)\end{array}$ & $\begin{array}{c}5 \\
13 \\
36\end{array}$ & $\begin{array}{l}(1.0) \\
(5.0) \\
(1.0)\end{array}$ & $\begin{array}{c}6 \\
25 \\
37\end{array}$ & $\begin{array}{c}(30.0) \\
(1.0) \\
(10.0)\end{array}$ & $\begin{array}{c}9 \\
26 \\
38\end{array}$ & $\begin{array}{c}(1.0) \\
(5.0) \\
(40.0)\end{array}$ & $\begin{array}{l}10 \\
34 \\
42\end{array}$ & $\begin{array}{c}(10.0) \\
(5.0) \\
(15.0)\end{array}$ \\
\hline & $E$ & $\begin{array}{r}2 \\
11 \\
35 \\
\end{array}$ & $\begin{array}{r}(40.0) \\
(1.0) \\
(5.0) \\
\end{array}$ & $\begin{array}{r}5 \\
25 \\
38 \\
\end{array}$ & $\begin{array}{r}(1.0) \\
(1.0) \\
(15.0) \\
\end{array}$ & $\begin{array}{r}6 \\
27 \\
43 \\
\end{array}$ & $\begin{array}{l}(65.0) \\
(20.0) \\
(20.0) \\
\end{array}$ & $\begin{array}{c}9 \\
33\end{array}$ & $\begin{array}{l}(15.0) \\
(20.0)\end{array}$ & $\begin{array}{l}10 \\
34\end{array}$ & $\begin{array}{l}(5.0) \\
(5.0)\end{array}$ \\
\hline \multirow{5}{*}{ A. senegal } & A & $\begin{array}{c}2 \\
26\end{array}$ & $\begin{array}{l}(10.0) \\
(10.0)\end{array}$ & $\begin{array}{c}6 \\
34\end{array}$ & $\begin{array}{l}(5.0) \\
(5.0)\end{array}$ & $\begin{array}{c}7 \\
38\end{array}$ & $\begin{array}{c}(4.0) \\
(20.0)\end{array}$ & 10 & $(5.0)$ & 13 & $(15.0)$ \\
\hline & B & $\begin{array}{r}1 \\
34 \\
49\end{array}$ & $\begin{array}{c}(1.0) \\
(5.0) \\
(10.0)\end{array}$ & $\begin{array}{c}2 \\
35\end{array}$ & $\begin{array}{c}(40.0) \\
(5.0)\end{array}$ & $\begin{array}{c}6 \\
38\end{array}$ & $\begin{array}{l}(40.0) \\
(40.0)\end{array}$ & $\begin{array}{c}9 \\
39\end{array}$ & $\begin{array}{c}(50.0) \\
(1.0)\end{array}$ & $\begin{array}{l}26 \\
44\end{array}$ & $\begin{array}{r}(10.0) \\
(1.0)\end{array}$ \\
\hline & $\mathrm{C}$ & $\begin{array}{c}2 \\
11 \\
38\end{array}$ & $\begin{array}{c}(40.0) \\
(2.0) \\
(20.0)\end{array}$ & $\begin{array}{c}5 \\
13 \\
39\end{array}$ & $\begin{array}{l}(1.0) \\
(2.0) \\
(1.0)\end{array}$ & $\begin{array}{c}6 \\
26 \\
44\end{array}$ & $\begin{array}{c}(10.0) \\
(5.0) \\
(1.0)\end{array}$ & $\begin{array}{c}7 \\
34\end{array}$ & $\begin{array}{l}(30.0) \\
(5.0)\end{array}$ & $\begin{array}{l}10 \\
36\end{array}$ & $\begin{array}{l}(1.0) \\
(1.0)\end{array}$ \\
\hline & $\mathrm{D}$ & $\begin{array}{c}2 \\
26\end{array}$ & $\begin{array}{c}(40.0) \\
(5.0)\end{array}$ & $\begin{array}{c}6 \\
34\end{array}$ & $\begin{array}{l}(3.0) \\
(5.0)\end{array}$ & $\begin{array}{l}10 \\
38\end{array}$ & $\begin{array}{l}(10.0) \\
(40.0)\end{array}$ & $\begin{array}{l}11 \\
41\end{array}$ & $\begin{array}{c}(1.0) \\
(10.0)\end{array}$ & 13 & $(20.0)$ \\
\hline & $\mathrm{E}$ & $\begin{array}{r}1 \\
11 \\
\end{array}$ & $\begin{array}{l}(1.0) \\
(1.0) \\
\end{array}$ & $\begin{array}{c}2 \\
26 \\
\end{array}$ & $\begin{array}{c}(20.0) \\
(5.0) \\
\end{array}$ & $\begin{array}{r}5 \\
34 \\
\end{array}$ & $\begin{array}{c}(1.0) \\
(15.0)\end{array}$ & $\begin{array}{r}6 \\
38 \\
\end{array}$ & $\begin{array}{c}(5.0) \\
(60.0)\end{array}$ & 10 & $(15.0)$ \\
\hline \multirow{5}{*}{ B. aegyptiaca } & A & $\begin{array}{c}2 \\
26 \\
45\end{array}$ & $\begin{array}{l}(1.0) \\
(10.0) \\
(2.0)\end{array}$ & $\begin{array}{r}6 \\
34 \\
49\end{array}$ & $\begin{array}{c}(30.0) \\
(5.0) \\
(20.0)\end{array}$ & $\begin{array}{c}9 \\
37\end{array}$ & $\begin{array}{c}(30.0) \\
(1.0)\end{array}$ & $\begin{array}{l}11 \\
38\end{array}$ & $\begin{array}{l}(1.0) \\
(1.0)\end{array}$ & $\begin{array}{l}13 \\
39\end{array}$ & $\begin{array}{l}(2.0) \\
(1.0)\end{array}$ \\
\hline & B & $\begin{array}{c}5 \\
38\end{array}$ & $\begin{array}{l}(1.0) \\
(20.0)\end{array}$ & $\begin{array}{c}6 \\
39\end{array}$ & $\begin{array}{c}(55.0) \\
(1.0)\end{array}$ & $\begin{array}{l}10 \\
42\end{array}$ & $\begin{array}{l}(5.0) \\
(1.0)\end{array}$ & 26 & $(5.0)$ & 34 & $(5.0)$ \\
\hline & $\mathrm{C}$ & $\begin{array}{r}2 \\
38\end{array}$ & $\begin{array}{l}(10.0) \\
(5.0)\end{array}$ & 5 & $(5.0)$ & 6 & $(25.0)$ & 9 & $(70.0)$ & 26 & $(5.0)$ \\
\hline & $\mathrm{D}$ & $\begin{array}{r}6 \\
38\end{array}$ & $\begin{array}{l}(1.0) \\
(30.0)\end{array}$ & $\begin{array}{c}9 \\
41\end{array}$ & $\begin{array}{l}(5.0) \\
(1.0)\end{array}$ & 13 & $(20.0)$ & 32 & $(10.0)$ & 34 & $(1.0)$ \\
\hline & $\mathbf{E}$ & $\begin{array}{c}7 \\
26\end{array}$ & $\begin{array}{l}(2.0) \\
(5.0)\end{array}$ & $\begin{array}{l}9 \\
29\end{array}$ & $\begin{array}{l}(30.0) \\
(10.0)\end{array}$ & $\begin{array}{l}10 \\
37\end{array}$ & $\begin{array}{l}(2.0) \\
(2.0)\end{array}$ & $\begin{array}{l}13 \\
38\end{array}$ & $\begin{array}{l}(10.0) \\
(10.0)\end{array}$ & $\begin{array}{l}18 \\
45\end{array}$ & $\begin{array}{c}(5.0) \\
(10.0)\end{array}$ \\
\hline
\end{tabular}




\begin{tabular}{|c|c|c|c|c|c|c|c|c|c|c|c|c|}
\hline \multirow[t]{5}{*}{ Awash } & \multirow{5}{*}{ A. tortilis } & A & $\begin{array}{r}8 \\
32\end{array}$ & $\begin{array}{l}(10.0) \\
(10.0)\end{array}$ & $\begin{array}{l}12 \\
46\end{array}$ & $\begin{array}{l}(5.0) \\
(5.0)\end{array}$ & 14 & $(30.0)$ & 15 & $(20.0)$ & 16 & $(5.0)$ \\
\hline & & B & $\begin{array}{l}12 \\
27\end{array}$ & $\begin{array}{l}(20.0) \\
(10.0)\end{array}$ & $\begin{array}{l}14 \\
47\end{array}$ & $\begin{array}{c}(10.0) \\
(1.0)\end{array}$ & $\begin{array}{l}15 \\
48\end{array}$ & $\begin{array}{c}(20.0) \\
(2.0)\end{array}$ & 16 & $(5.0)$ & 17 & $(5.0)$ \\
\hline & & $\mathrm{C}$ & $\begin{array}{l}12 \\
21\end{array}$ & $\begin{array}{l}(5.0) \\
(5.0)\end{array}$ & $\begin{array}{l}14 \\
29\end{array}$ & $\begin{array}{l}(50.0) \\
(10.0)\end{array}$ & $\begin{array}{l}15 \\
47\end{array}$ & $\begin{array}{c}(20.0) \\
(1.0)\end{array}$ & $\begin{array}{l}16 \\
50\end{array}$ & $\begin{array}{c}(5.0) \\
(10.0)\end{array}$ & $\begin{array}{l}19 \\
51\end{array}$ & $\begin{array}{l}(5.0) \\
(2.0)\end{array}$ \\
\hline & & D & 12 & $(2.0)$ & 14 & $(2.0)$ & 16 & $(20.0)$ & 52 & $(60.0)$ & & \\
\hline & & $\mathbf{E}$ & 8 & $(5.0)$ & 12 & $(5.0)$ & 14 & $(10.0)$ & 16 & $(60.0)$ & 17 & $(10.0)$ \\
\hline & \multirow{5}{*}{ A. senegal } & A & $\begin{array}{c}8 \\
19\end{array}$ & $\begin{array}{l}(5.0) \\
(5.0)\end{array}$ & $\begin{array}{l}12 \\
29\end{array}$ & $\begin{array}{c}(5.0) \\
(10.0)\end{array}$ & 14 & $(10.0)$ & 15 & $(20.0)$ & 16 & $(5.0)$ \\
\hline & & B & $\begin{array}{l}14 \\
48\end{array}$ & $\begin{array}{l}(20.0) \\
(10.0)\end{array}$ & 16 & $(5.0)$ & 19 & $(5.0)$ & 22 & $(5.0)$ & 47 & $(5.0)$ \\
\hline & & $\mathrm{C}$ & $\begin{array}{l}12 \\
47\end{array}$ & $\begin{array}{l}(10.0) \\
(5.0)\end{array}$ & 14 & $(10.0)$ & 15 & $(20.0)$ & 16 & $(10.0)$ & 19 & $(5.0)$ \\
\hline & & $\mathrm{D}$ & $\begin{array}{l}12 \\
24\end{array}$ & $\begin{array}{l}1(5.0) \\
(2.0)\end{array}$ & $\begin{array}{l}14 \\
27\end{array}$ & $\begin{array}{c}(2.0) \\
(10.0)\end{array}$ & 15 & $(10.0)$ & 16 & $(50.0)$ & 17 & $(20.0)$ \\
\hline & & E & 16 & $(70.0)$ & 23 & $(20.0)$ & & & & & & \\
\hline & \multirow{5}{*}{ B. aegyptiaca } & $\mathrm{A}$ & 15 & $(10.0)$ & 19 & $(10.0)$ & 20 & $(30.0)$ & 29 & $(10.0)$ & 32 & $(5.0)$ \\
\hline & & B & $\begin{array}{l}16 \\
32\end{array}$ & $\begin{array}{l}(2.0) \\
(40.0)\end{array}$ & $\begin{array}{l}19 \\
50\end{array}$ & $\begin{array}{l}(10.0) \\
(75.0)\end{array}$ & 21 & $(5.0)$ & 23 & $(10.0)$ & 29 & $(20.0)$ \\
\hline & & $\mathrm{C}$ & $\begin{array}{l}19 \\
53\end{array}$ & $\begin{array}{l}(10.0) \\
(2.0)\end{array}$ & 23 & $(20.0)$ & 24 & $(5.0)$ & 48 & $(5.0)$ & 50 & $(10.0)$ \\
\hline & & D & 12 & $(10.0)$ & 16 & $(15.0)$ & 23. & (2.0) & 50 & $(40.0)$ & & \\
\hline & & $\mathrm{E}$ & $\begin{array}{l}12 \\
54 \\
\end{array}$ & $\begin{array}{l}(40.0) \\
(10.0) \\
\end{array}$ & $\begin{array}{r}14 \\
55 \\
\end{array}$ & $\begin{array}{c}(5.0) \\
(20.0) \\
\end{array}$ & 15 & $(30.0)$ & 47 & $(2.0)$ & 50 & $(10.0)$ \\
\hline \multirow{15}{*}{ Abijata } & \multirow{5}{*}{$\begin{array}{l}\text { Shalla } \\
\text { A. tortilis }\end{array}$} & A & $\begin{array}{c}2 \\
30\end{array}$ & $\begin{array}{l}(40.0) \\
(10.0)\end{array}$ & $\begin{array}{c}3 \\
56\end{array}$ & $\begin{array}{l}(10.0) \\
(50.0)\end{array}$ & $\begin{array}{c}9 \\
57\end{array}$ & $\begin{array}{c}(1.0) \\
(20.0)\end{array}$ & $\begin{array}{l}25 \\
58\end{array}$ & $\begin{array}{l}(1.0) \\
(2.0)\end{array}$ & $\begin{array}{l}26 \\
59\end{array}$ & $\begin{array}{c}(10.0) \\
(1.0)\end{array}$ \\
\hline & & B & $\begin{array}{c}2 \\
31\end{array}$ & $\begin{array}{l}(1.0) \\
(5.0)\end{array}$ & $\begin{array}{r}3 \\
41\end{array}$ & $\begin{array}{c}(60.0) \\
(1.0)\end{array}$ & $\begin{array}{l}10 \\
60\end{array}$ & $\begin{array}{c}(40.0) \\
(1.0)\end{array}$ & $\begin{array}{l}25 \\
62\end{array}$ & $\begin{array}{l}(1.0) \\
(5.0)\end{array}$ & 26 & $(5.0)$ \\
\hline & & $C$ & $\begin{array}{c}2 \\
29\end{array}$ & $\begin{array}{l}(30.0) \\
(15.0)\end{array}$ & $\begin{array}{c}3 \\
31\end{array}$ & $\begin{array}{l}(5.0) \\
(5.0)\end{array}$ & $\begin{array}{c}9 \\
58\end{array}$ & $\begin{array}{c}(25.0) \\
(2.0)\end{array}$ & $\begin{array}{l}26 \\
60\end{array}$ & $\begin{array}{c}(40.0) \\
(1.0)\end{array}$ & 28 & $(1.0)$ \\
\hline & & $\mathrm{D}$ & $\begin{array}{c}3 \\
38\end{array}$ & $\begin{array}{c}(80.0) \\
(5.0)\end{array}$ & $\begin{array}{c}9 \\
63\end{array}$ & $\begin{array}{c}(20.0) \\
(5.0)\end{array}$ & 13 & $(10.0)$ & 26 & $(10.0)$ & 28 & $(5.0)$ \\
\hline & & $\mathrm{E}$ & 2 & $(60.0)$ & 3 & $(50.0)$ & 9 & $(5.0)$ & 26 & $(50.0)$ & 61 & $(10.0)$ \\
\hline & \multirow{5}{*}{ A. senegal } & $\bar{A}$ & $\begin{array}{c}2 \\
31\end{array}$ & $\begin{array}{l}(1.0) \\
(1.0)\end{array}$ & $\begin{array}{c}9 \\
38\end{array}$ & $\begin{array}{l}(5.0) \\
(2.0)\end{array}$ & $\begin{array}{l}10 \\
56\end{array}$ & $\begin{array}{c}(4.0) \\
(70.0)\end{array}$ & $\begin{array}{l}26 \\
58\end{array}$ & $\begin{array}{l}(5.0) \\
(1.0)\end{array}$ & 29 & $(20.0)$ \\
\hline & & B & $\begin{array}{c}2 \\
29\end{array}$ & $\begin{array}{l}(5.0) \\
(50.0)\end{array}$ & $\begin{array}{r}3 \\
31\end{array}$ & $\begin{array}{c}(60.0) \\
(5.0)\end{array}$ & $\begin{array}{c}9 \\
35\end{array}$ & $\begin{array}{l}(5.0) \\
(5.0)\end{array}$ & $\begin{array}{l}26 \\
61\end{array}$ & $\begin{array}{c}(10.0) \\
(5.0)\end{array}$ & $\begin{array}{l}28 \\
62\end{array}$ & $\begin{array}{l}(5.0) \\
(5.0)\end{array}$ \\
\hline & & $\mathrm{C}$ & 3 & $(60.0)$ & 26 & $(50.0)$ & & & & & & \\
\hline & & $\mathrm{D}$ & 3 & $(70.0)$ & 9 & $(20.0)$ & 26 & $(50.0)$ & & & & \\
\hline & & $\mathrm{E}$ & $\begin{array}{r}1 \\
61 \\
\end{array}$ & $\begin{array}{l}(2.0) \\
(5.0) \\
\end{array}$ & $\begin{array}{r}3 \\
62 \\
\end{array}$ & $\begin{array}{r}(1.0) \\
(60.0) \\
\end{array}$ & 9 & $(10.0)$ & 18 & $(1.0)$ & 26 & $(90.0)$ \\
\hline & \multirow{5}{*}{ B. aegyptiaca } & A & 1 & $(1.0)$ & 3 & $(80.0)$ & 9 & $(1.0)$ & 26 & $(10.0)$ & 64 & $(1.0)$ \\
\hline & & B & 9 & $(1.0)$ & 26 & $(20.0)$ & & & & & & \\
\hline & & $\mathrm{C}$ & 29 & $(15.0)$ & 60 & $(1.0)$ & 61 & $(5.0)$ & 64 & $(5.0)$ & & \\
\hline & & $\mathrm{D}$ & $\begin{array}{c}2 \\
37\end{array}$ & $\begin{array}{l}(5.0) \\
(5.0)\end{array}$ & $\begin{array}{c}3 \\
43\end{array}$ & $\begin{array}{l}(70.0) \\
(10.0)\end{array}$ & $\begin{array}{l}25 \\
65\end{array}$ & $\begin{array}{c}(10.0) \\
(5.0)\end{array}$ & 26 & $(10.0)$ & 36 & $(20.0)$ \\
\hline & & $\mathrm{E}$ & 1 & $(1.0)$ & 9 & $(2.0)$ & 26 & $(90.0)$ & 43 & $(1.0)$ & 61 & $(10.0)$ \\
\hline
\end{tabular}




\section{Appendix 2. List of undercanopy species recorded from the three sites.}

\begin{tabular}{|c|c|c|c|}
\hline No. & Species name & No. & Species name \\
\hline 1. & Lippia trifolia & 33. & Acacia seyal Del. \\
\hline 2. & Solanum incanum $\mathrm{L}$. & 34. & Bidens pilosa \\
\hline 3. & Hypoestes forskaolii (Vagk.) R. B. & 35. & Setaria verticillata \\
\hline 4. & Achyranthes aspera $\mathrm{L}$. & 36. & Commelina benghalensis $\mathrm{L}$. \\
\hline 5. & Galinsoga parviflora Cav. & 37. & Solanum schimperi \\
\hline 6. & Tagetes minuta $\mathrm{L}$. & 38. & Chloris gayana Kunth \\
\hline 7. & Solanum nigrum $\mathrm{L}$. & 39. & Euphorbia petitiana A. Rich. \\
\hline 8. & Vernonia sp. & 40. & Acacia sieberiana DC. \\
\hline 9. & Satureja abyssinica (Benth.) Briq. & 41. & Erucastrum sp. \\
\hline 10. & Harpachne schimperi Hochst. ex A. Rich. & 42. & Cineraia abyssinica \\
\hline 11. & Cryptostegia grandiflora R. Br. & 43. & Sida sp. \\
\hline 12. & Grewia villosa Willd. & 44. & Erucastrum abyssinica \\
\hline 13. & Hyperrhenia hirta (L.) Stapf. & 45. & Eragrostis tenuifolia (A. Rich.) Steud. \\
\hline 14. & Bothriochloa radicans (Lehm.) A. Camus & 46. & Digitaria rivae (Chiov.) Stapf. \\
\hline 15. & Chrysopogon plumulosus Hochst. & 47. & Pupalia lappacea Juss. \\
\hline 16. & Ischaemum afrum (J.F. Gmel) Dandy & 48. & Seddera latifolia Hochst \& Steud. \\
\hline 17. & Cordia gharaf (Forssk.) Ehrenb ex Ashers & .49 . & Enteropogon macrostachys (A. Rich.) Benth \\
\hline 18. & Sida ovata Forssk. & 50. & Cymbopogon sp. \\
\hline 19. & Barleria quadrispina Lindau & 51. & Seddera lancolata \\
\hline 20. & Cymbopogon excavatus (Hochst.) Stapf. & 52. & Lintonia nutans Stapf. \\
\hline 21. & Vernonia cinerea (L.) Less & 53. & Solanum benderaianum Engl \\
\hline 22. & Dactyloctenium scindicum Boiss & 54. & Hibiscus triona \\
\hline 23. & Acacia nubica Benth & 55. & Grewia tricolata (SP.) \\
\hline 24. & Vernonia cinerea (L.) Less & 56. & Cenchrus setigerus Vahl \\
\hline 25 . & Abutilon bidentatum (Hochst.) A. Rich. & 57. & Ceropegia cufodritii Chiov. \\
\hline 26. & Cenchrus ciliaris $\mathrm{L}$. & 58. & Sida rhombitolia $\mathrm{L}$. \\
\hline 27. & Acacia tortilis (Forssk.) Hayne & 59. & Leptadinia arborea \\
\hline 28. & Pavonia arabica Boiss & 60. & Notonia abyssinica A. Rich. \\
\hline 29. & Acacia senegal (L.) Willd & 61. & Ischaemum sp. \\
\hline 30. & Abutilon figarianum Webb. & 62. & Heteropogon contortus (L.) Roem. \& Shult. \\
\hline 31. & $\begin{array}{l}\text { Eragrostis papposa (Roem. \& Schult.) } \\
\text { Steud }\end{array}$ & $\begin{array}{l}63 . \\
64 .\end{array}$ & $\begin{array}{l}\text { Cypholepis yemenica (Schweinf.) Chiov. } \\
\text { Sonchus asper (L.) Hill }\end{array}$ \\
\hline & Balanites aegyptiaca (L.) Del. & 65. & Cordia sp. \\
\hline
\end{tabular}

